\title{
Field evaluation of resistance of winter wheat to powdery mildew (Blumeria graminis f. sp. tritici) and identification of the gene Pm2 in selected genotypes
}

\author{
Polowa ocena odporności na mączniaka prawdziwego zbóż i traw \\ (Blumeria graminis f. sp. tritici) oraz identyfikacja genu Pm2 \\ w wybranych genotypach pszenicy ozimej
}

\author{
Danuta Kurasiak-Popowska*, Agnieszka Tomkowiak, Dorota Weigt, Sylwia Mikołajczyk, Jerzy Nawracała
}

\begin{abstract}
Summary
The aim of this study was the analysis of infection of winter wheat by Blumeria graminis $\mathrm{f}$. $\mathrm{sp}$. tritici in field conditions and identification of the gene Pm2 using SSR markers. Winter wheat genotypes containing the resistance genes for leaf rust ( $L r 19$ or $L r 50)$ or containing semi-dwarfing genes (RhtB1, RhtD1 and Rht8) were examined. Field observations were conducted at the Agricultural Research Station Dłoń $\left(51^{\circ} 41^{\prime} 23.835^{\prime \prime} \mathrm{N} 17^{\circ} 4^{\prime} 1.414 " \mathrm{E}\right)$ in the years 2014-2016. The analyzed wheat genotypes showed varied resistance to powdery mildew under field conditions. To identify the gene Pm2 two markers were used: Xgwm205 and Xcfd81. As a result of the analysis of both markers specific products were observed in the 16 genotypes of wheat. Specific amplification products did not appear in the genotypes: Agatha, Klasic and Ludwig when Xcfd81 was used; and in 3 genotypes containing Lr19 when analysis were carried out with marker Xgwm205. The differences in results for a total of five cultivars may be linked to various allelic forms in a locus Pm2.
\end{abstract}

Key words: wheat; powdery mildew of cereals and grasses; SSR markers

\section{Streszczenie}

Celem pracy była polowa ocena porażenia pszenicy ozimej przez Blumeria graminis f. sp. tritici oraz identyfikacja genu Pm2 za pomocą markerów SSR w tych materiałach. Jako materiał wykorzystano genotypy pszenicy ozimej zawierające geny odporności na rdzę brunatną ( $L r 19$ lub Lr50) lub zawierające geny półkarłowatości (RhtB1, RhtD1 i Rht8). Obserwacje polowe przeprowadzono w latach 2014-2016 w Rolniczym Gospodarstwie Doświadczalnym Dłoń (5141'23.835"N 17²'1.414"E). Analizowane genotypy pszenicy charakteryzowały się zróżnicowaną polową odpornością na mączniaka prawdziwego zbóż i traw. W wyniku analiz molekularnych specyficzne produkty amplifikacji dla Xgwm205 oraz Xcfd81 świadczące o obecności genu Pm2 zaobserwowano w 16 genotypach pszenicy ozimej. Specyficzne produkty amplifikacji nie pojawiły się w genotypach: Agatha, Klasic i Ludwig przy analizach przeprowadzonych w wykorzystaniem Xcfd81 oraz w 3 genotypach zawierających Lr19 dla markera Xgwm205. Różnice w wynikach dotyczące w sumie pięciu odmian są prawdopodobnie skutkiem występowania różnych form allelicznych w locus $P m 2$.

Słowa kluczowe: pszenica; mączniak prawdziwy zbóż i traw; markery SSR

\footnotetext{
Uniwersytet Przyrodniczy w Poznaniu

Dojazd 11, 60-632 Poznań

*corresponding author: dkurasiak@wp.pl
} 


\section{Wstęp / Introduction}

Znajomość genotypów pod względem ich odporności na choroby grzybowe i inne, ważne pod względem hodowlanym cechy, pomaga $\mathrm{w}$ świadomym wyborze komponentów rodzicielskich do krzyżowania oraz w selekcji korzystnych genotypów w dalszych etapach hodowli. Ocena badanych cech fenotypowych tradycyjnie przebiega w warunkach polowych oraz w ostatnich latach polega na analizach molekularnych przy użyciu markerów specyficznych. Markery molekularne sprzężone $\mathrm{z}$ genami odporności umożliwiają selekcję w kierunku odporności na daną chorobę przy braku patogenów (Langridge i wsp. 2001). Piramidyzacja kilku genów w jednej odmianie może zapewnić bardziej trwałą odporność na choroby, ponieważ jest mniej prawdopodobne, aby w populacji patogenu doszło jednocześnie do wielu mutacji dotyczących każdego genu oporności (McDonald i Linde 2002).

Do identyfikacji genów odporności na mączniaka prawdziwego zbóż i traw bardzo często wykorzystuje się dwa typy markerów molekularnych: markery mikrosatelitarne (SSR - Single Sequence Repeat) oraz STS (Sequence Target Site). Przy udziale tych dwóch typów markerów molekularnych zidentyfikowano wiele z genów odporności na mączniaka prawdziwego zbóż i traw, przy czym geny Pm1, Pm 2, Pm3, Pm4, Pm5, Pm8 i Pm24 mają więcej niż jeden allel nadający oporność (Miranda i wsp. 2006; Ma i wsp. 2016): Pm1e (Singrün i wsp. 2003), Pm3g (Bougot i wsp. 2002), Pm3h, Pm3i, Pm3j (Huang i wsp. 2004), Pm4a (Ma i wsp. 2004), Pm4b (Yi i wsp. 2008), Pm 4c (Hao i wsp. 2008), Pm5e (Huang i wsp. 2003), Pm8 (Mohler i wsp. 2001). Do tej pory zidentyfikowano 17 funkcjonalnych alleli w locus Pm3, co czyniło go jednym z największych genów oporności roślinnej (Bhullar i wsp. 2010). W przypadku Pm2, zidentyfikowano Pm2a (pszenica Ulka), Pm2b (linia KM2939), PmPB3558 (linia PB3558), Pm2c z chińskich landów Niaomai, PmX3986-2 (linia X3986-2), PmWFJ (Wanfengjian 34) i PmD57-5D (linia D57-5D), PmLX66 (chińska odmiana Liangxing 66), PmZ155 (chińska odmiana Zhongmai 155), PmW14 (chińska odmiana Wennong 14) i PmYB (chińska odmiana YingBo700) (McIntosh i Baker 1970; Ma i wsp. 2011, 2014, 2015a, b, c; Huang i wsp. 2012; Song i wsp. 2014; Lu i wsp. 2015; Sun i wsp. 2015; Xu i wsp. 2015).

Najbardziej ekonomicznym i efektywnym rozwiązaniem jest wprowadzenie do jednej odmiany genów odporności nie tylko na jedną, ale na różne choroby. Pogłębiona charakterystyka materiałów referencyjnych, zgromadzonych jako materiały wyjściowe ma duże znaczenie w hodowli roślin.

Celem pracy była polowa ocena porażenia przez Blumeria graminis f. sp. tritici genotypów referencyjnych pszenicy ozimej ze znanymi genami odporności na rdzę brunatną ( $L r 19$ lub Lr50) i genami półkarłowatości (RhtB1, RhtD1 lub Rht8) oraz identyfikacja genu Pm2 za pomocą markerów SSR w tych materiałach.

\section{Materiały i metody / Materials and methods}

Jako materiał wykorzystano genotypy referencyjne pszenicy ozimej zawierające geny odporności na rdzę brunatną ( $L r 19$ lub Lr50) lub zawierające wybrane geny półkarłowatości (RhtB1, RhtD1 lub Rht8) otrzymane z National Smalle Grain Collection, NPGS, USA oraz genotypy pszenicy ozimej znajdujące się w kolekcji Katedry Genetyki i Hodowli Roślin (KGiHR) Uniwersytetu Przyrodniczego w Poznaniu (tab. 1).

Tabela 1. Stopień odporności na porażenie przez Blumeria graminis f. sp. tritici w warunkach polowych (Rolnicze Gospodarstwo Doświadczalne Dłoń) oraz identyfikacja genu $P m 2$ za pomocą dwóch markerów SSR

Table 1. The degree of resistance to infection by powdery mildew Blumeria graminis f. sp. tritici in the field conditions (Agricultural Research Station Dłoń) and identification of the gene Pm2 by two SSR markers

\begin{tabular}{|c|c|c|c|c|c|c|c|}
\hline \multirow{2}{*}{$\begin{array}{l}\text { Lp. } \\
\text { No. }\end{array}$} & \multirow{2}{*}{$\begin{array}{l}\text { Genotyp } \\
\text { Genotype }\end{array}$} & \multirow{2}{*}{$\begin{array}{l}\text { Geny } \\
\text { Genes }\end{array}$} & \multicolumn{3}{|c|}{$\begin{array}{l}\text { Warunki polowe } \\
\text { Field conditions }\end{array}$} & \multicolumn{2}{|c|}{$\begin{array}{l}\text { Analizy molekularne } \\
\text { Molecular analysis }\end{array}$} \\
\hline & & & $2013 / 2014$ & $2014 / 2015$ & $2015 / 2016$ & Xcfd81 & Xgwm205 \\
\hline 1 & D347 & $\operatorname{Lr} 19$ & 3,5 & 5,5 & 4,5 & + & - \\
\hline 2 & Agatha & $\operatorname{Lr} 19$ & 1,5 & 2 & 1,5 & - & - \\
\hline 4 & Lr19 & $\operatorname{Lr} 19$ & 2 & 1,5 & 6,5 & + & + \\
\hline 5 & TAM 107 & $\operatorname{Lr50}$ & 6,5 & 2,5 & 3,5 & + & + \\
\hline 6 & Karl 92 & $\operatorname{Lr50}$ & 4,5 & 2,5 & 2,5 & + & + \\
\hline 7 & KS96WGRC36 & $\operatorname{Lr} 50$ & 8 & 2 & 5,5 & + & + \\
\hline 8 & Greer & Rht8 (174 pz - bp) & 2,5 & 1,5 & 5,5 & + & + \\
\hline 10 & Klasic & Rht8 (165 pz - bp) & 7,5 & 2,5 & 2 & - & + \\
\hline 11 & Geneva & Rht8 (174 pz - bp) & 6 & 3 & 7,5 & + & + \\
\hline 12 & Clark & Rht B1a, Rht D1a & 6,5 & 3 & 1,5 & + & + \\
\hline 13 & Pioneer var 2548 & Rht8 (174 pz - bp) & 6,5 & 2,5 & 6 & + & + \\
\hline
\end{tabular}




\begin{tabular}{c|c|c|c|c|c|c|c}
\hline 1 & 2 & 3 & 4 & 5 & 6 & 7 & 8 \\
\hline 14 & Pioneer var 2545 & Rht B1a, Rht D1b & 6,5 & 2,5 & 5,5 & + & + \\
\hline 15 & $2737 \mathrm{~W}$ & Rht8 $(204 \mathrm{pz}-\mathrm{bp})$ & 7 & 2,5 & 6,5 & + & + \\
\hline 16 & Freedom & Rht B1b, Rht D1a & 5,5 & 2 & 7 & + & + \\
\hline 17 & OK 101 & Rht B1a, Rht D1b & 1,5 & 1 & 7,5 & + & + \\
\hline 18 & Ok 102 & Rht B1b, Rht D1a & 5,5 & 1,5 & 2,5 & + & + \\
\hline 19 & Ludwig & - & 6,5 & 3,5 & 6 & - & + \\
\hline 20 & Muszelka & - & 5,5 & 6,5 & 5,5 & + & + \\
\hline 21 & Ozon & - & 8 & 7,5 & 5,5 & + & + \\
\hline
\end{tabular}

skala $9^{\circ}: 1$ - pełne porażenie, 9 - brak objawów chorobowych - $9^{\circ}$ scale: 1 - severe infection, 9 - no symptoms of infection „," oznacza obecność danego fragmentu DNA charakterystycznego dla locus Xcfd81 lub Xgwm205

"+" indicates the presence of a particular DNA fragment specific to the Xcfd81 or Xgwm205 locus

„-” oznacza brak danego fragmentu DNA charakterystycznego dla locus Xcfd81 lub Xgwm205

"- " means no specific DNA fragment specific for the Xcfd81 or Xgwm205 locus

Doświadczenie polowe założone zostało w Stacji Doświadczalnej KGiHR mieszczącej się w Rolniczym Gospodarstwie Doświadczalnym Dłoń Uniwersytetu Przy-

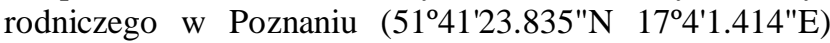
w latach 2014-2016. Wybrane genotypy wysiewano na poletkach o powierzchni $1 \mathrm{~m}^{2}(1 \mathrm{~m} \times 1 \mathrm{~m})$, w układzie bloków losowanych, w trzech powtórzeniach. Ocena stopnia porażenia roślin przez $B$. graminis f. sp. tritici dokonywana była w oparciu o 9-stopniową skalę, w której 9 - oznacza brak objawów chorobowych, a 1 - najsilniejsze porażenie.

Materiał do analiz molekularnych pobrano z 10-dniowych siewek uzyskanych ze skiełkowanych w warunkach laboratoryjnych ziaren. Izolację DNA prowadzono wykorzystując zestaw do izolacji DNA z roślin Genomic Mini AX PLANT firmy A\&A BIOTECHNOLOGY zgodnie z dołączoną procedurą. Stężenie DNA oznaczono za pomocą spektrofotometru NanoDrop. Próby rozcieńczano wodą destylowaną w celu uzyskania jednolitego stężenia $40 \mathrm{ng} / \mu \mathrm{l}$. Reakcję PCR (polymerase chain reaction) przeprowadzono w mieszaninie o składzie: woda $-5 \mu \mathrm{l}$, DreamTaq ${ }^{\mathrm{TM}}$ Green PCR Master Mix - 6,25 $\mu \mathrm{l}$, startery $2 \times 0,25 \mu \mathrm{l}$ (stężenie końcowe starterów wynosiło $20 \mu \mathrm{M}$ ), matryca DNA - $1 \mu \mathrm{l}$. W celu stwierdzenia obecności genu Pm2 w odmianach wykorzystano dwa specyficzne markery: Xgwm205 i Xcfd81, do identyfikacji których użyto następujących par starterów:

\section{Xgwm205 - F:5’CGACCCGGTTCACTTCAG3’, R:5’AGTCGCCGTTGTATAGTGCC3',}

\section{Xcfd81 - F:5’TATCСССААТССССТСТT3’, R:5’GTCAATTGTGGCTTGTCCCT3'.}

Do badań wykorzystano termocykler gradientowy TProffesional Basic Gradient Thermocycler. Po zoptymalizowaniu reakcję PCR przeprowadzono w tych samych warunkach niezależnie od identyfikowanego markera, profil różnił się tylko temperaturą przyłączania starterów ustaloną zgodnie $\mathrm{z}$ temperaturą ich topnienia: denaturacja wstępna -3 min. w $94^{\circ} \mathrm{C}, 40$ cykli (denaturacja - $30 \mathrm{~s}$ w $94^{\circ} \mathrm{C}$, przyłączanie starterów -1 min. w $54^{\circ} \mathrm{C}, 58^{\circ} \mathrm{C}$, $63^{\circ} \mathrm{C}$, synteza $-1 \mathrm{~min}$. $\mathrm{w} 72^{\circ} \mathrm{C}$ ), synteza końcowa $-5 \mathrm{~min}$. w $72^{\circ} \mathrm{C}$, przechowywanie max. $24 \mathrm{~h} \mathrm{w} 4^{\circ} \mathrm{C}$.

Elektroforezę prowadzono w żelu agarozowym o stężeniu 2,5\%. Wizualizacji dokonano na transiluminatorze High Performance UV Transilumiantor UVP. Obrazy archiwizowano za pomocą systemu KTE - Video.

\section{Wyniki i dyskusja / Results and discussion}

W czasie trwania badań polowych zaobserwowano wyższe temperatury $w$ okresie od marca do lipca we wszystkich latach badań w porównaniu do wielolecia, przy

Tabela 2. Miesięczne sumy opadów i średnie miesięczne temperatury powietrza w Rolniczym Gospodarstwie Doświadczalnym Dłoń w latach 2014-2016

Table 2. Sums of rainfall and mean air temperatures in Agricultural Research Station Dłoń in 2014-2016

\begin{tabular}{|c|c|c|c|c|c|c|c|c|}
\hline \multirow[t]{2}{*}{$\begin{array}{l}\text { Miesiąc } \\
\text { Month }\end{array}$} & \multicolumn{4}{|c|}{$\begin{array}{c}\text { Średnia temperatura powietrza } \\
\text { Average air temperature } \\
{\left[{ }^{\circ} \mathrm{C}\right]}\end{array}$} & \multicolumn{4}{|c|}{$\begin{array}{c}\text { Suma opadów } \\
\text { Precipitation total } \\
\text { [mm] }\end{array}$} \\
\hline & 2014 & 2015 & 2016 & 1956-2009 & 2014 & 2015 & 2016 & 1956-2009 \\
\hline Marzec - March & 6,9 & 3,9 & 1,0 & 3,0 & 46,6 & 54,8 & 61,0 & 33,7 \\
\hline Kwiecień - April & 11,5 & 8,3 & 8,8 & 8,2 & 41,3 & 26,0 & 54,5 & 32,0 \\
\hline Maj-May & 15,4 & 14,8 & 16,3 & 13,5 & 135,2 & 30,1 & 57,5 & 55,3 \\
\hline Czerwiec - June & 19,5 & 17,7 & 21,0 & 16,8 & 27,6 & 33,2 & 72,5 & 66,2 \\
\hline Lipiec - July & 23,9 & 21,7 & 19,5 & 18,4 & 69,6 & 53,1 & 128,2 & 82,1 \\
\hline
\end{tabular}


czym w roku 2014 zaobserwowany wzrost temperatur był najwyższy (tab. 2). W roku 2015 po deszczowym marcu zanotowano bardzo małą ilość opadów w kolejnych miesiącach, co sprawiło, iż w analizowanym okresie czasu suma opadów w Rolniczym Gospodarstwie Doświadczalnym Dłoń była niższa niż w wieloleciu. W latach 2014 i 2016 odnotowano więcej opadów niż w wieloleciu.

Polowe wyniki porażenia przez mączniaka prawdziwego zbóż i traw były bardzo zróżnicowanie w latach badań. Wysokie, średnie i niskie porażenie genotypów pszenicy ozimej obserwowano w każdym roku badań. Bardzo niskie porażenie odmiany Ozon zaobserwowano w pierwszych dwóch latach badań, odmiana Muszelka odznaczała się średnim poziomem porażenia, a odmiana Agatha wysokim przez wszystkie lata badań. W przypadku pozostałych genotypów porażenie było zmienne w latach. Związane jest to $\mathrm{z}$ faktem, iż wirulencja izolatów reprezentujących populację B. graminis f. sp. tritici na terenie Polski jest bardzo złożona (Pietrusińska i Czembor 2014), a z drugiej strony obecnie poznano 41 genów Pm odporności na B. graminis f. sp. tritici (Czajowski i Czembor 2016). Pięć z tych loci (Pm1, Pm 2, Pm3, Pm4, Pm5, Pm8 i Pm24) mają więcej niż jeden allel nadający oporność (Miranda i wsp. 2006; Ma i wsp. 2016).

Jedynie niektóre $\mathrm{z}$ tych genów warunkują efektywną odporność na mączniaka prawdziwego zbóż i traw, co wiąże się ze zdolnościami adaptacyjnymi i migracją patogena (Czajowski i Czembor 2016). Analiza wirulencji i struktura populacji $B$. graminis f. sp. tritici na terenie Polski w latach 2008-2013 została przedstawiona przez Pietrusińską i Czembora (2014) oraz Czajowskiego i Czembora (2016). W doświadczeniach tych zaobserwowano, że populacja B. graminis występująca na pszenicy charakteryzuje się szerokim spektrum wirulencji, a występujące izolaty odznaczają się patogenicznością wobec większości odmian i linii pszenicy z genami Pm. W związku z tym należy poszukiwać nowych źródeł odporności i dążyć do kumulowania genów odporności w jednym genotypie. Ma i wsp. (2011) uważają, iż Pm2 może być bardzo użyteczny w połączeniu $\mathrm{z}$ innymi genami odporności na mączniaka prawdziwego zbóż i traw. Obecność wielu form allelicznych genu Pm2 odpowiada za różny poziom odporności genotypów na $B$. graminis f. sp. tritici i znacząco zwiększa zróżnicowanie w tym locus (Ma i wsp. 2016).

W przedstawionej pracy oceniono obecność genu Pm2 za pomocą markerów Xgwm205 i Xcfd81. W trakcie analiz stwierdzono bardzo dużą powtarzalność wyników. W wyniku analiz markerem Xcfd81 specyficzny produkt o długości 283 pz, świadczący o obecności genu Pm2 zaobserwowano w 18 genotypach pszenicy ozimej (rys. 1). Markera nie zaobserwowano w genotypach Agatha, Klasic i Ludwig. Wykorzystując marker Xgwm205 specyficzny produkt amplifikacji o długości 143 pz (świadczący o obecności
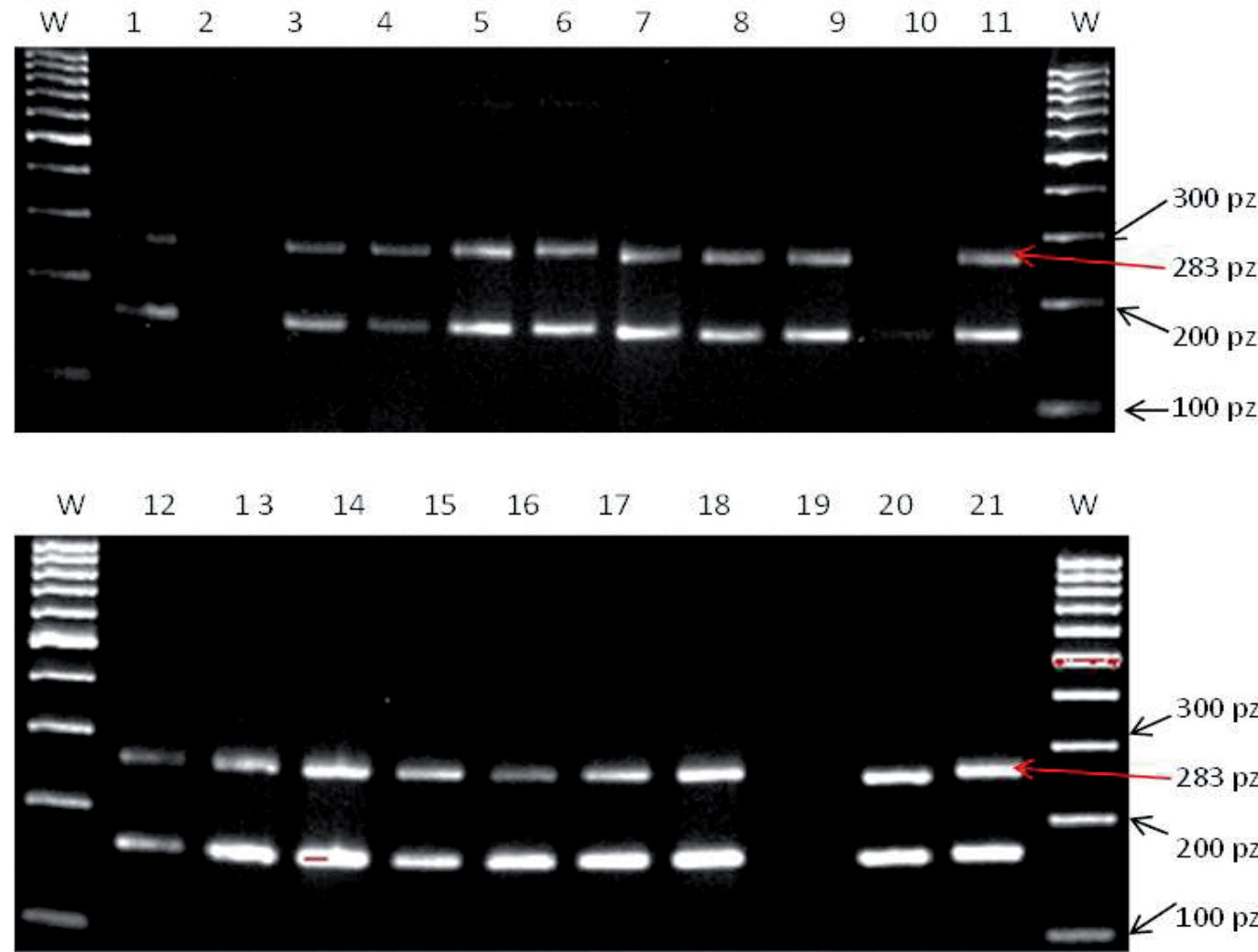

$p z-b p$

Rys. 1. Obraz elektroforetyczny produktów PCR w 2,5\% żelu agarozowym po włączeniu do reakcji markera Xcfd81. W - marker masy cząsteczkowej O'RangeRuler 100 pz. Kolejność genotypów na żelu została zamieszczona w tabeli 1.

Fig. 1. Electrophoresis of PCR products on 2.5\% agarose gel with marker Xcfd81. W - O'RangeRuler molecular weight marker of $100 \mathrm{bp}$. The order of genotypes in gel according to Table 1. 

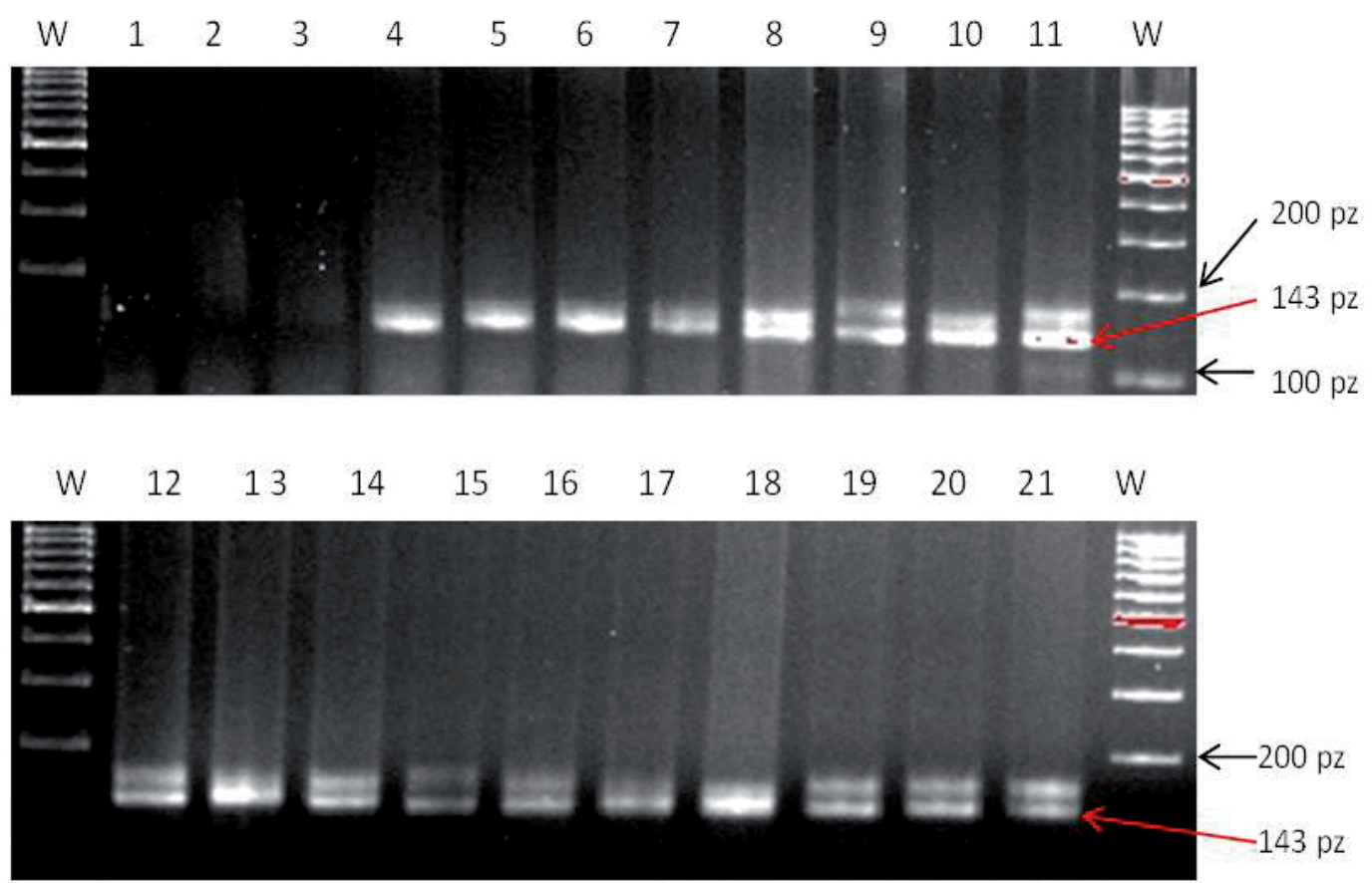

$\mathrm{pz}-\mathrm{bp}$

Rys. 2. Obraz elektroforetyczny produktów PCR w 2,5\% żelu agarozowym po włączeniu do reakcji markera Xgwm205. W - marker masy cząsteczkowej O'RangeRuler 100 pz. Kolejność genotypów na żelu została zamieszczona w tabeli 1.

Fig. 2. Electrophoresis of PCR products on 2.5\% agarose gel with marker Xgwm205. W - O'RangeRuler molecular weight marker of $100 \mathrm{bp}$. The order of genotypes in gel according to Table 1.

genu Pm2) zidentyfikowano u 18 genotypów. Produkt o tej wielkości nie pojawił się w genotypach zawierających gen Lr19: D347, Agatha i Thatcher (rys. 2). Różnice w wynikach dotyczące $\mathrm{w}$ sumie pięciu odmian są prawdopodobnie skutkiem występowania w badanych genotypach różnych alleli w locus Pm2. Ma i wsp. (2016) zauważają, że podobnie jak w przypadku Pm3, identyfikuje się coraz więcej alleli $P m 2 \mathrm{z}$ różnymi widmami odpowiedzi na izolaty $B$. graminis f. sp. tritici zwiększając tym samym różnorodność w tym locus. Autorzy sugerują dalsze badania w celu rozróżnienia tych alleli, w tym mapowanie i re-sekwencjonowanie.

Spośród genotypów zawierających geny odporności na rdzę brunatną, najmniej porażonymi genotypami przez B. graminis f. sp. tritici były genotypy: D347 zawierający Lr19 oraz KS96WGRC36 z genem Lr50. Analizując trzy geny półkarłowatości najsłabiej porażanymi genotypami zawierającymi Rht8 były Geneva i $2737 \mathrm{~W}$, a geny Rht $B 1 b$ (Rht1) oraz $R h t-D 1 b$ (Rht2) genotypy Pioneer var 2545 oraz Freedom.

Wiedza uzyskana na podstawie przeprowadzonych analiz molekularnych pozwala na możliwość świadomego wykorzystania genotypów w programach hodowlanych. Wyniki polowe pokazują, iż żaden $\mathrm{z}$ analizowanych genotypów nie odznaczał się małą wrażliwością na B. graminis f. sp. tritici w czasie trzech lat badań, co oznacza konieczność kumulacji kolejnych genów odporności na mączniaka prawdziwego zbóż i traw w tych materiałach. Pietrusińska i Czembor (2017) podkreślają, iż w programach hodowlanych dąży się do kumulowania dwóch lub trzech genów odporności Pm.

\section{Wnioski / Conclusions}

1. Najsłabiej porażonymi genotypami przez B. graminis f. sp. tritici były genotypy: D347 zawierający gen Lr19, KS96WGRC36 z genem Lr50, Geneva i 2737W z Rht8 Pioneer var 2545 z genami RhtB1a, RhtD1b oraz Freedom z genami Rht B1b i Rht D1a.

2. Specyficzne produkty amplifikacji dla markerów Xgwm 205 i Xcfd81 świadczące o obecności genu Pm2 odporności na mączniaka prawdziwego zbóż i traw zidentyfikowano w 16 genotypach referencyjnych pszenicy.

\section{Literatura / References}

Bhullar N.K., Zhang Z.Q., Wicker T., Keller B. 2010. Wheat gene bank accessions as a source of new alleles of the powdery mildew resistance gene Pm3: a large scale allele mining project. BMC Plant Biology 10: 88. DOI: 10.1186/1471-2229-10-88.

Bougot Y., Lemoine J., Pavoine M.T., Barloy D., Doussinault G. 2002. Identification of a microsatellite associated with Pm3 resistance alleles to powdery mildew in wheat. Plant Breeding 121 (4): 325-329. DOI: 10.1046/j.1439-0523.2002.736127.x. 
Czajowski G., Czembor P. 2016. Chorobotwórczość Blumeria graminis f. sp. tritici i Blumeria graminis f. sp. triticale sprawców mączniaka prawdziwego zbóż i traw na pszenicy i pszenżycie. [Pathogenicity of Blumeria graminis f. sp. tritici and Blumeria graminis f. sp. triticale the causal agents of wheat and triticale powdery mildew]. Progress in Plant Protection 56 (3): 360-365. DOI: 10.14199/ppp-2016-058.

Hao Y., Liu A., Wang Y., Feng D., Gao J., Li X., Liu S., Wang H. 2008. Pm23: a new allele of Pm4 located on chromosome 2AL in wheat. Theoretical and Applied Genetics 117 (8): 1205-1212. DOI: 10.1007/s00122-008-0827-y.

Huang X.Q., Hsam S.L.K., Mohler V., Röder M.S., Zeller F.J. 2004. Genetic mapping of three alleles at the Pm3 locus conferring powdery mildew resistance in common wheat (Triticum aestivum L.). Genome 47 (6): 1130-1136. DOI: 10.1139/g04-079.

Huang X.Q., Wang L.X., Xu M.X., Röder M.S. 2003. Microsatellite mapping of the powdery mildew resistance gene Pm5e in common wheat (Triticum aestivum L.). Theoretical and Applied Genetics 106 (5): 858-865. DOI: 10.1007/s00122-002-1146-3.

Huang J., Zhao Z.H., Song F.J., Wang X.M., Xu H.X., Huang Y., An D.G., Li H.J. 2012. Molecular detection of a gene effective against powdery mildew in the wheat cultivar Liangxing 66. Molecular Breeding 30 (4): 1737-1745. DOI: 10.1007/s11032-012-9757-0.

Langridge P., Lagudah E.S., Holton T.A., Appels R., Sharp P.J., Chalmers K.J. 2001. Trends in genetics and genome analyses in wheat: A review. Australian Journal of Agricultural Research 52 (12): 1043-1077. DOI: 10.1071/AR01082.

Lu Y.Q., Wu X.Y., Yao M.M., Zhang J.P., Liu W.H., Yang X.M., Li X.Q., Du J., Gao A.N., Li L.H. 2015. Genetic mapping of a putative Agropyron cristatum-derived powdery mildew resistance gene by a combination of bulked segregant analysis and single nucleotide polymorphism array. Molecular Breeding 35: 96. DOI: 10.1007/s11032-015-0292-7.

Ma H.Q., Kong Z.X., Fu B.S., Li N., Zhang L.X., Jia H.Y., Ma Z.Q. 2011. Identyfication and mapping of a new powdery mildew resistance gene on chromosome 6D of common wheat. Theoretical and Applied Genetics 123: 1099-1106. DOI: 10.1007/s00122$-011-1651-3$.

Ma Z.Q., Wei J.B., Chen S.H. 2004. PCR-based markers for the powdery mildew resistance gene Pm4a in wheat. Theoretical and Applied Genetics 109 (1): 140-145. DOI: 10.1007/s00122-004-1605-0.

Ma P.T., Xu H., Li L., Zhang H., Han G., Xu Y., Fu X., Zhang X., An D.G. 2016. Characterization of a new Pm2 allele conferring powdery mildew resistance in the wheat germplasm line FG-1. Frontiers in Plant Science 7: 546. DOI: 10.3389/fpls.2016.00546.

Ma P.T., Xu H.X., Luo Q.L., Qie Y.M., Zhou Y.L., Xu Y.F., Han H., Li L.H. 2014. Inheritance and genetic mapping of a gene for seedling resistance to powdery mildew in wheat line X3986-2. Euphytica 200: 149-157. DOI: 10.3390/ijms160817231.

Ma P.T., Xu H.X., Xu Y.F., Li L.H., Qie Y.M., Luo Q.L., Zhang X., Li X., Zhou Y., An D.G. 2015a. Molecular mapping of a new powdery mildew resistance gene Pm2b in Chinese breeding line KM2939. Theoretical and Applied Genetics 128 (4): $613-622$. DOI: $10.1007 / \mathrm{s} 00122-015-2457-5$.

Ma P.T., Xu H.X., Zhang H.X., Li L.H., Xu Y.F., Zhang X.T., An D.G. 2015b. The gene PmWFJ is a new member of the complex Pm2 locus conferring unique powdery mildew resistance in wheat breeding line Wanfengjian 34. Molecular Breeding 35: 210. DOI: 10.1007/s11032-015-0403-5.

Ma P.T., Zhang H.X., Xu H.X., Xu Y.F., Cao Y.W., Zhang X.T., An D.G. 2015c. The gene PmYB confers broad-spectrum powdery mildew resistance in the multi-allelic Pm2 chromosome region of the Chinese wheat cultivar YingBo 700. Molecular Breeding 35: 124. DOI: 10.1007/s11032-015-0320-7.

McDonald B.A., Linde C. 2002. Pathogen population genetics, evolutionary potential, and durable resistance. Annual Review of Phytopathology 40: 349-379. DOI: 10.1146/annurev.phyto.40.120501.101443.

McIntosh R.A., Baker E.P. 1970. Cytogenetic studies in wheat iv. Chromosomal location and linkage studies involving the Pm2 locus for powdery mildew resistance. Euphytica 19 (1): 71-77. DOI: 10.1007/BF01904668.

Miranda L.M., Murphy J.P., Marshall D., Leath S. 2006. Pm34: a new powdery mildew resistance gene transferred from Aegilops tauschii Coss. to common wheat (Triticum aestivum L.). Theoretical and Applied Genetics 113 (8): 1497-1504. DOI: 10.1007/ /s00122-006-0397-9.

Mohler V., Hsam S.L.K., Zeller F.J., Wenzel G. 2001. An STS marker distinguishing the rye-derived powdery mildew resistance alleles at the Pm8/Pm17 locus of common wheat. Plant Breeding 120 (5): 448-450. DOI: 10.1046/j.1439-0523.2001.00622.x.

Pietrusińska A., Czembor J.H. 2014. Struktura wirulencji populacji Blumeria graminis f. sp. tritici występującej na terenie Polski w latach 2012-2013. [Virulence structure of the Blumeria graminis f. sp. tritici population occurring in Poland across 2012-2013]. Biuletyn Instytutu Hodowli i Aklimatyzacji Roślin 274: 15-25.

Pietrusińska A., Czembor J.H. 2017. Piramidowanie genów odporności (Pm21 + Pm34) pszenicy ozimej na mączniaka prawdziwego zbóż i traw (Blumeria graminis f. sp. tritici). [Pyramiding winter wheat resistance genes (Pm21 + Pm34) of powdery mildew of cereals and grasses (Blumeria graminis f. sp. tritici)]. Progress in Plant Protection 57 (1): 41-46. DOI:10.14199/ppp-2017-006.

Singrün Ch., Hsam S.L.K., Hartl L., Zeller F.J., Mohler V. 2003. Powdery mildew resistance gene Pm22 in cultivar Virest is a member of the complex Pm1 locus in common wheat (Triticum aestivum L. em Thell.). Theoretical and Applied Genetics 106 (8): 1420-1424. DOI: 10.1007/s00122-002-1187-7.

Song W., Sun H.G., Sun Y.L., Zhao Z.H., Wang X.M., Wu X.F., Li H.J. 2014. Chromosomal localization of the gene for resistance to powdery mildew in the wheat cultivar Wennong 14. Acta Agronomica Sinica 40 (5): 798-804. DOI: 10.3724/SP.J.1006. .2014.00798.

Sun Y.L., Zou J.W., Sun H.G., Song W., Wang X.M., Li H.J. 2015. PmLX66 and PmW14: New alleles of Pm2 for resistance to powdery mildew in the Chinese winter wheat cultivars Liangxing 66 and Wennong 14. Plant Diseases 99 (8): 1118-1124. DOI: 10.1094/ /PDIS-10-14-1079-RE.

Xu H.X., Yi Y.J., Ma P.T., Qie Y.M., Fu X.Y., Xu Y.F., Zhang X.T., An D.G. 2015. Molecular tagging of a new broad-spectrum powdery mildew resistance allele Pm2c in Chinese wheat landrace Niaomai. Theoretical and Applied Genetics 128 (10): $2077-2084$. DOI: 10.1007/s00122-015-2568-z.

Yi Y.J., Liu H.Y., Haung X.Q., An L.Z., Wang F., Wang X.L. 2008. Development of molecular markers linked to the wheat powdery mildew resistance gene Pm4b and marker validation for molecular breeding. Plant Breeding 127 (2): 116-120. DOI: 10.1111/j.1439-0523.2007.01443.x. 